\title{
Pengujian dan Analisis Lower Guard Frame pada Kendaraan Bak Terbuka Menggunakan Metode FEA Static Analysis
}

\author{
Tono Sukarnoto ${ }^{1, ~ a, ~ R i c k y ~ H a r t o ~ N u g r o h o ~}{ }^{2, b}$ and Yusep Mujalis $3, c$ \\ 1,2,3 Universitas Trisakti, Jakarta Indonesia

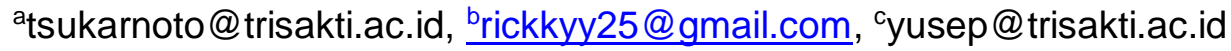

\begin{abstract}
Abstrak.
Kementerian perhubungan dalam hal ini Direktorat Jenderal Perhubungan Darat mengeluarkan surat edaran Nomor: SE.2/AJ.307/DRJD/2018 yang mewajibkan pemasangan teralis pelindung bawah pada kendaraan barang dengan berat kotor maksimum $3500 \mathrm{~kg}$. Pelindung ini untuk melindungi dinding belakang kabin dari dorongan muatan yang bergeser pada kondisi tertentu.

Kendaraan pick up Daihatsu Himax awalnya belum dilengkapi dengan pelindung dimaksud. Untuk memenuhi surat edaran tersebut dibuatlah pelindung yang selanjutnya disebut lower guard frame (LGF). Penelitian ini mengevaluasi kinerja dari LGF terhadap beban Tarik dan tekan dengan cara pengujian dan melakukan analisis kekuatan dengan metode elemen hingga. Hasilnya LGF cukup kuat untuk diaplikasikan. Untuk displacement hasil pengujian lebih besar dari pada hasil MEH, namun posisi kritis yang diperoleh sama.
\end{abstract}

Kata kunci. pick-up, bingkai pelindung bawah, uji kekuatan, FEA.

\begin{abstract}
.
Ministry of Transportation, qq Directorat General of Land Transportation, has issued new regulation for pick-up truck in circular letter number: SE.2/AJ.307/DRJD/2018 that regulated mandatory installment of lower guard frame for pick-up truck with maximum gross vehicle weight (GVW) 3.500 kgs. The guard function is to protect rear cabin panel from loading goods displacement under certain circumstances.

One of the pick-up truck is Daihatsu Himax, that from initial design was not equipped with lower guard frame. This research conduct to evaluate the performance of lower guard frame fo Himax. Strength analysis was done by Finite Element Analysis (FEA) and compared with testing in factory. The result shows that lower guard structure was strong enough to applied in the vehicle and for displacement, results from testing are higher than from FEA, but the critical locations are similar.
\end{abstract}

Keywords: pick-up, lower guard frame, uji kekuatan, FEA. 


\section{Latar Belakang}

Pada Peraturan Pemerintahan Republik Indonesia No 55 tahun 2012 pasal 55 menjelaskan mengenai ketentuan dan regulasi mengenai kendaraan di Indonesia. Kendaraan adalah suatu sarana angkut di jalan yang terdiri atas kendaraan bermotor dan kendaraan tidak bermotor. Kendaraan bermotor adalah setiap kendaraan yang digerakkan oleh peralatan mekanik berupa mesin selain kendaraan yang berjalan di atas rel. Kendaraan tidak bermotor adalah setiap kendaraan yang digerakkan oleh tenaga manusia dan/atau hewan. Salah satu kendaraan bermotor adalah mobil barang. Mobil barang adalah kendaraan bermotor yang dirancang sebagian atau seluruhnya untuk mengangkut barang. Salah satu jenis mobil barang yang ada di Indonesia adalah mobil bak muatan terbuka [1].

Dalam upaya memastikan keselamatan dan kemanan lalu lintas tidak terkecuali terhadap kendaraan barang, Kementerian Perhubungan melalui Direktorat Jenderal Perhubungan Darat mengeluarkan ketentuan baru yang mengatur mengenai bak kendaraan barang. Surat Edaran Nomor: SE.2/AJ.307/DRJD/2018 telah ditandatangani Dirjen Perhubungan Darat Budi Setiyadi pada awal Maret 2018. Dalam surat edaran ini, ada hal yang mengatur soal ketentuan pemasangan perangkat pelindung (teralis) khususnya pada kendaraan barang bak terbuka dengan JBB maksimal 3.500 kilogram. JBB atau yang disebut jumlah berat yang diperbolehkan adalah berat maksimum kendaraan bermotor berikut muatannya yang diperbolehkan menurut rancangannya. Teralis harus dipasang pada jendela kabin belakang dari lantai bak muatan sampai menutupi jendela kabin belakang. Dengan adanya ketentuan baru ini mengharuskan para produsen mobil kendaraan bak terbuka untuk melakukan penambahan komponen berupa pelindung teralis yang bertujuan untuk memenuhi regulasi baru yang telah ditetapkan [2].

Untuk memenuhi Surat Edaran tersebut produsen menambahkan perangkat pelindung atau teralis pada kendaraan barang produksinya. Salah satu tipe kendaraan yang ditambahkan pelindung tersebut adalah pick-up Himax. Pelindung Teralis bagian bawah atau disebut Lower Guard Frame (LGF) pada unit Himax merupakan suatu komponen baru. Pada komponen ini belum dilakukan pengujian dan analisis mengenai performa dan kemampuannya. LGF diharapkan mampu menahan beban Tarik arah longitudinal sebesar $2680 \mathrm{~N}$ dan beban arah vertikal sebesar $3940 \mathrm{~N}$.

Sebelum adanya pelindung teralis bagian bawah, beban muatan dari bak memiliki kontak langsung dengan panel bagian belakang kabin. Dengan adanya pelindung teralis, beban dari muatan tidak langsung kontak dengan panel bagian belakang kabin sehingga mengurangi resiko panel bagian belakang kabin rusak. Hal ini mungkin dapat mengakibatkan pengemudi dan penumpang di dalam kabin terkena dampak dari kerusakan kabin secara langsung. Oleh karena itu, perlu dilakukan evaluasi untuk mengetahui performa dan kemampuan LGF. Dalam hal ini, untuk mendapatkan evaluasi yang akurat perlu dilakukan pengujian secara aktual dan simulasi analisis menggunakan metode CAE.

Tujuan penelitian ini adalah mengetahui hubungan antara pengujian aktual dan analisis menggunakan CAE Analysis \& Simulation pada performa dan kemampuan LGF Himax.

\section{Tinjauan Pustaka}

Daihatsu Himax merupakan salah satu kendaraan bak terbuka yang diproduksi oleh PT Astra Daihatsu Motor. Daihatsu Himax memiliki mesin $1000 \mathrm{cc}$ dengan 3 silinder. Himax memiliki berat total kendaraan sebesar 1730 kilogram dan memiliki kapasitas muatan barang mencapai 750 kilogram. Himax dikategorikan sebagai kendaraan bak terbuka dengan jumlah berat beban (JBB) maksimal 3.500 kilogram [3]. Posisi LGF pada Himax dapat dilihat pada Gambar 1. 


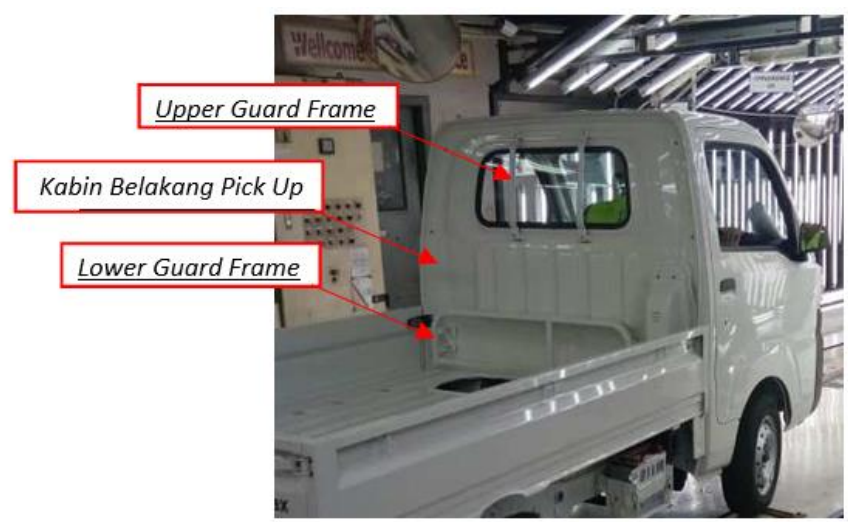

Gambar 1. Posisi LGF pada dinding belakang kabin.

Material yang digunakan pada komponen LGF dikategorikan menjadi 2 komponen pembentuk, yaitu baja lembaran dengan material SHGA270C dan pipa persegi dengan material STKM11A. Susunan komponen LGF ditunjukkan pada Gambar 2.

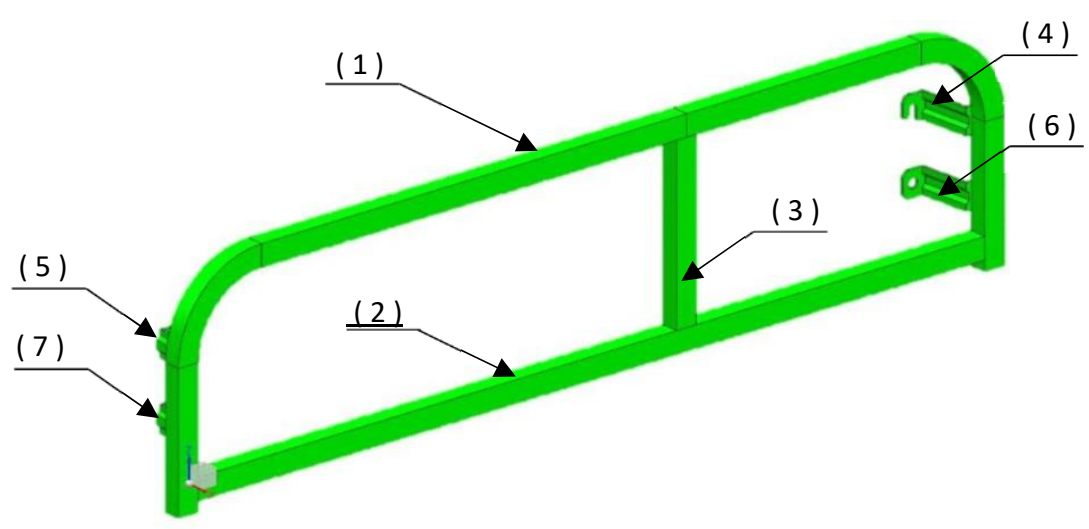

Gambar 2. Bagian LGF terbuat dari pipa baja persegi no 1,2 dan 3, sisanya dari baja lembaran [4].

Untuk keperluan pengujian dilakukan pengukuran gaya penarikan menggunakan load cell dan perpindahan menggunakan displacement gauge dengan prinsip LVDT (Linear Variable Differetial Transformer). LVDT terdiri dari satu kumparan primer di tengah dua kumparan sekunder dan inti magnetik yang bisa bergerak di tengahnya. Bila inti magnetik berada di tengah-tengah, tegangan dari kumparan sekunder 1 dan 2 akan seimbang sehingga tegangan luran nol. Pergerakan inti magnetik akan menghasilkan tegangan kumparan sekunder proporsional dengan jarak perpindahan [5].

Finite Element Analysis (FEA) tidak hanya digunakan di dunia benda padat, tetapi juga untuk analisis termal, perpindahan panas, mekanika fluida dan electromagnet. Untuk mekanika benda padat ada banyak aplikasi penggunaan FEA seperti statis dan dinamis, linear dan nonlinear, analisi tegangan dan perpindahan; getaran bebas dan paksa; perpindahan panas (yang dapat dikombinasikan dengan analisi tegangan dan perpindahan); ketidakstabilan elastis (buckling); akustik; elektrostatik dan magnetic [6]. 


\section{Metode}

Penelitian ini dilakukan dengan dua metode, pengujian fisik dan analisis FEA menggunakan Catia V5. Tahapan penelitian ini ditunjukkan pada Gambar 3.
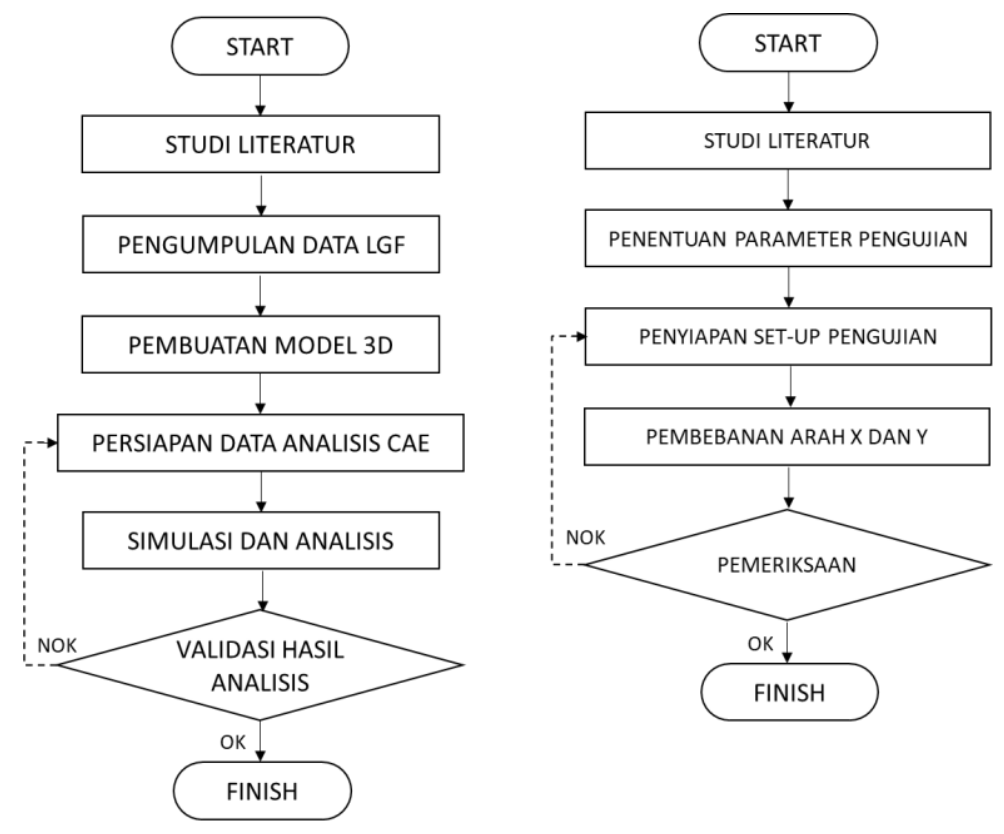

Gambar 3 Diagram alir analisis CAE (kiri) dan diagram alir pengujian (kanan)

Set up pengujian ditunjukkan pada Gambar 4, peralatan yang digunakan meliputi:

- Prototipe Lower Guard Frame ( Benda Uji )

- EDX Sensor Fusion

- Load cell

- Displacement Gauge

- Load Jig
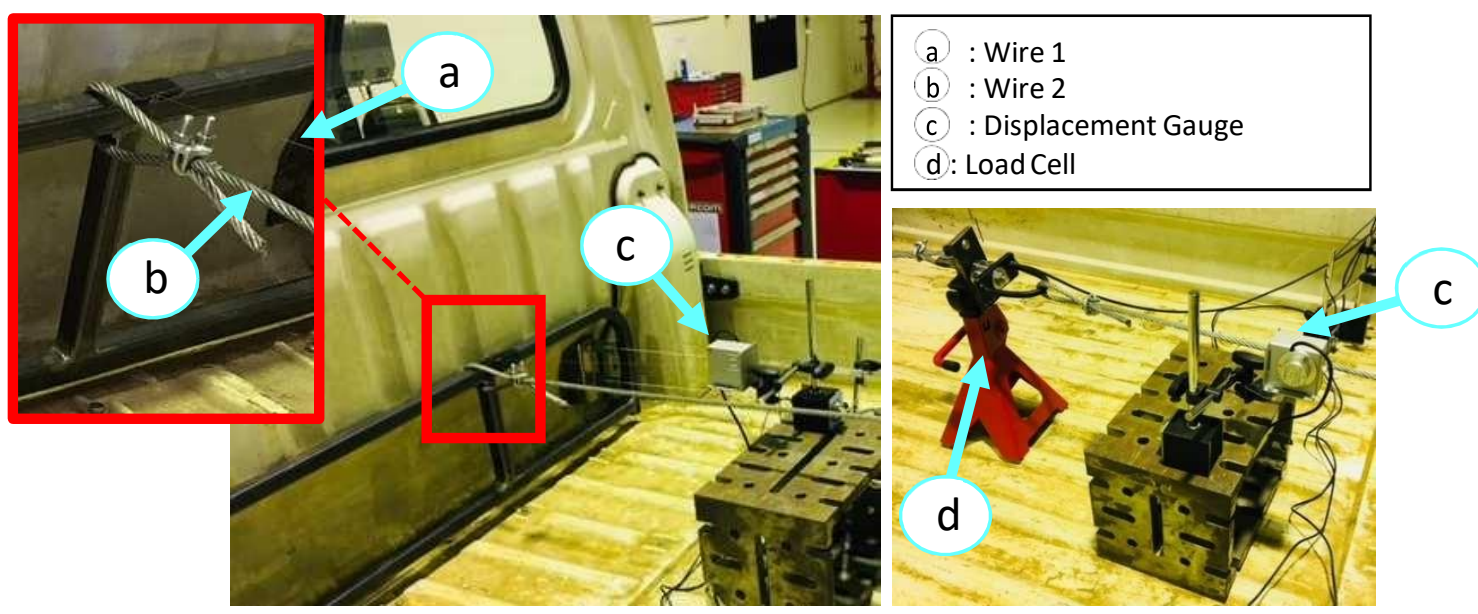

Gambar 4 Set-up pengujian tarik arah sumbu x. 
Pengujian dilakukan dengan penarikan pada arah sumbu x (arah longitudinal ke belakang) dan z (arah vertikal ke bawah) seperti ditunjukkan pada Gambar 5.
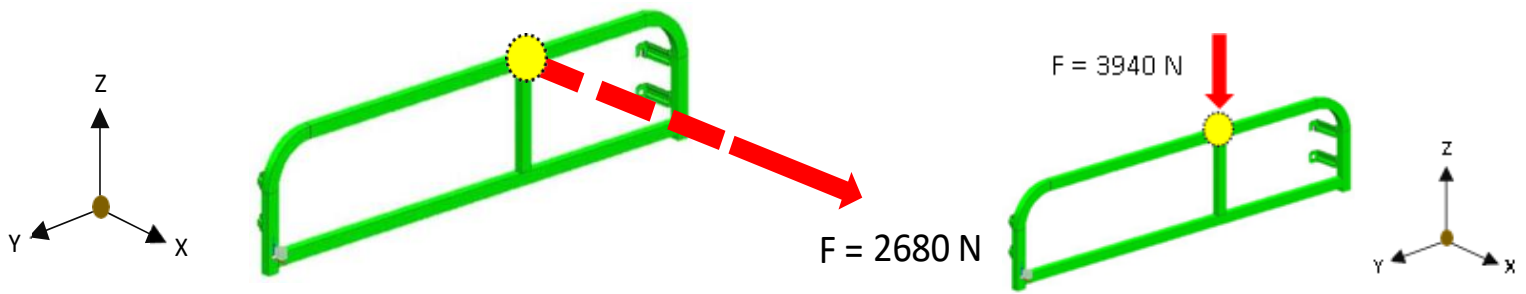

Gambar 5 Orientasi pengujian, penarikan arah sumbu x dan penekanan arah sumbu z.

\section{Hasil dan Diskusi}

\section{Pengujian Tarik arah sumbu $x$}

Data yang diperoleh pada penarikan arah sumbu x dengan beban $2680 \mathrm{~N}$ ditunjukkan pada Tabel 1.

Tabel 1. Hasil penarikan dengan gaya $2680 \mathrm{~N}$ arah sumbu $\mathrm{x}$.

\begin{tabular}{|l|r|r|r|}
\hline Komponen & Load [N] & \multicolumn{1}{|c|}{$\begin{array}{c}\text { Max. } \\
\text { Displacement } \\
{[\mathrm{mm}]}\end{array}$} & $\begin{array}{c}\text { Residual } \\
\text { isplacement } \\
{[\mathrm{mm}]}\end{array}$ \\
\hline Center Frame & 2680 & 50,5 & 30,2 \\
\hline Bracket RH UPR & 2680 & 21,2 & 13,5 \\
\hline Bracket RHLWR & 2680 & 6,7 & 3,5 \\
\hline & & & \\
\hline Bracket LHUPR & 2680 & 8,4 & \\
\hline
\end{tabular}

Terlihat deformasi terbesar terjadi pada tengah frame sebesar $50,5 \mathrm{~mm}$, ketika beban dilepas deformasi sisa atau deformasi plastis sebesar 30,2 mm. Jadi dengan penarikan pada pengujian ini terjadi deformasi plastis namun LGF tidak lepas dari dudukannya. Deformasi tersebut tidak hanya terjadi pada komponen LGF namun juga pada panel belakang kabin sebagai dudukan LGF.

\section{Pengujian tekan arah sumbu $z$.}

Pada pengujian ini terjadi deformasi maksimum pada titik tengah LGF. Fenomena yang terjadi pada pengujian kedua ini adalah saat beban yang diberikan mencapai 2990 N, LGF menyentuh bagian lantai bak kendaraan. Pada kondisi ini deformasi yang terjadi pada panel adalah sebesar $15 \mathrm{~mm}$. Pengujian dilanjutkan hingga beban yang diberikan mencapai $5160 \mathrm{~N}$. Target beban tercapai pada kondisi tegangan sebesar $3940 \mathrm{~N}$. Deformasi maksimumnya mencapai 28,3 mm. Adapun hasil dari pengujian kedua yang telah dilakukan ditunjukkan pada Tabel 2. 


\begin{tabular}{|l|r|r|}
\hline \multicolumn{1}{|c|}{ Komponen } & Load [N] & $\begin{array}{c}\text { Max. } \\
\text { Displacement } \\
{[\mathrm{mm}]}\end{array}$ \\
\hline Center Frame & 3940 & 28,3 \\
\hline Frame RH UPR & 3940 & 26,3 \\
\hline $\begin{array}{l}\text { Bracket RH UPR } \\
\text { Frame LH UPR }\end{array}$ & 3940 & 13 \\
\hline Bracket LH UPR & 3940 & 18,2 \\
\hline & 3940 & 5 \\
\hline
\end{tabular}

Tabel 2 Hasil penarikan arah sumbu y

\section{Analisis dengan Catia}

Persiapan awal analisis dengan Catia ditunjukkan pada Gambar 6. Untuk meshing digunakan octree tetrahedron dengan jenis elemen parabolik. Untuk material braket digunakan baja SHGA $270 \mathrm{C}-45$ dengan $\sigma_{\mathrm{y}}=195 \mathrm{MPa}$ dan material retainer SCGA $270 \mathrm{C}-45$ dengan $\sigma_{\mathrm{y}}=285 \mathrm{MPa}$.
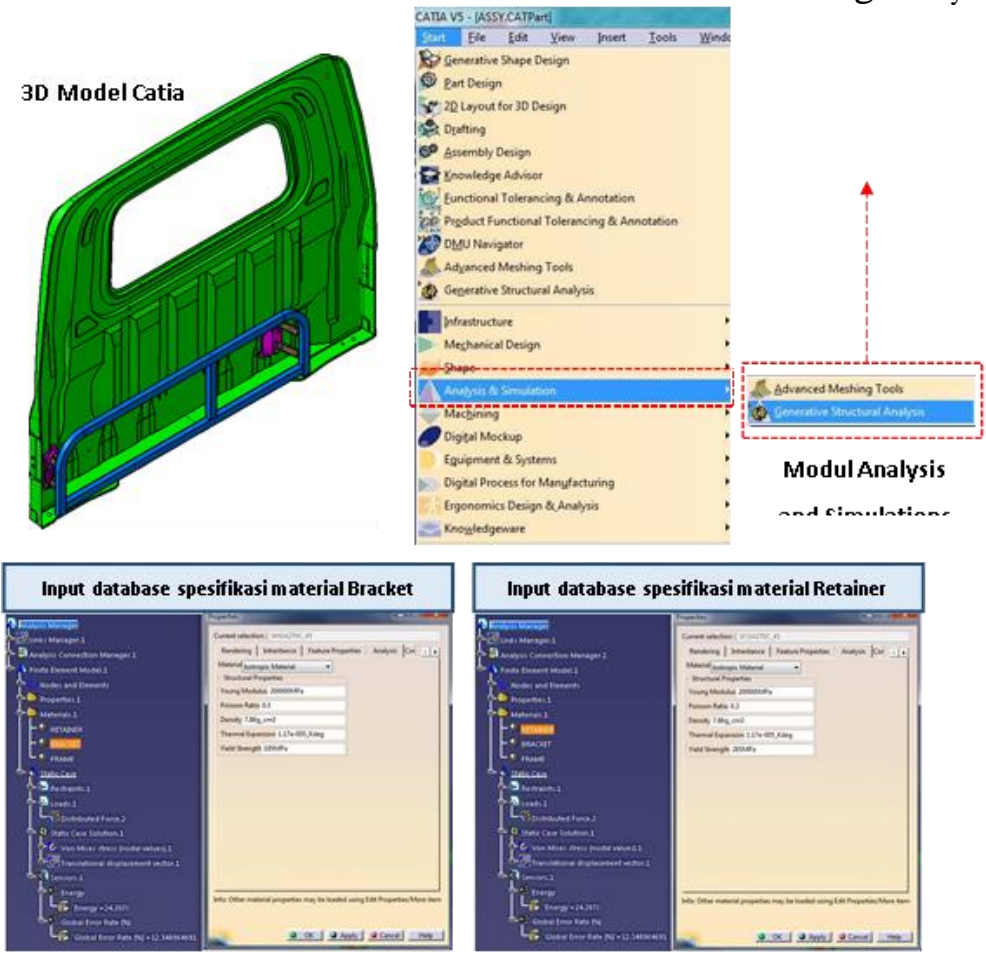

Gambar 6. Penyiapan analisis dengan Catia

Proses meshing dilakukan pada setiap komponen pembentuk LGF, kemudian dilakukan pemeriksaan kualitas meshing yang ditunjukkan pada Gambar 7. Selanjutnya dilakukan connecting antar komponen, pemberian batas (boundary) dan pembebanan. 


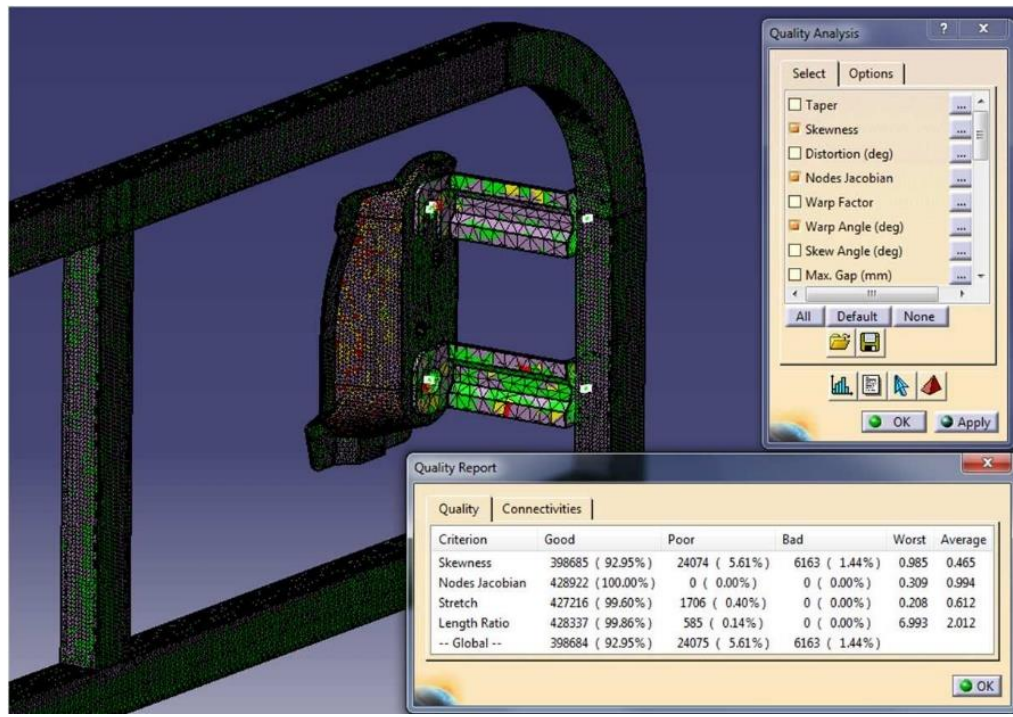

Gambar 7 Pemeriksaan kualitas meshing.

\section{Analisis Pembebanan Arah x}

Pembebanan dilakukan seperti pada pengujian yaitu penarikan arah sumbu $\mathrm{x}$ dan penekanan arah sumbu y. Hasil analisis Catia untuk arah x ditunjukkan pada Gambar 8 dan 9.

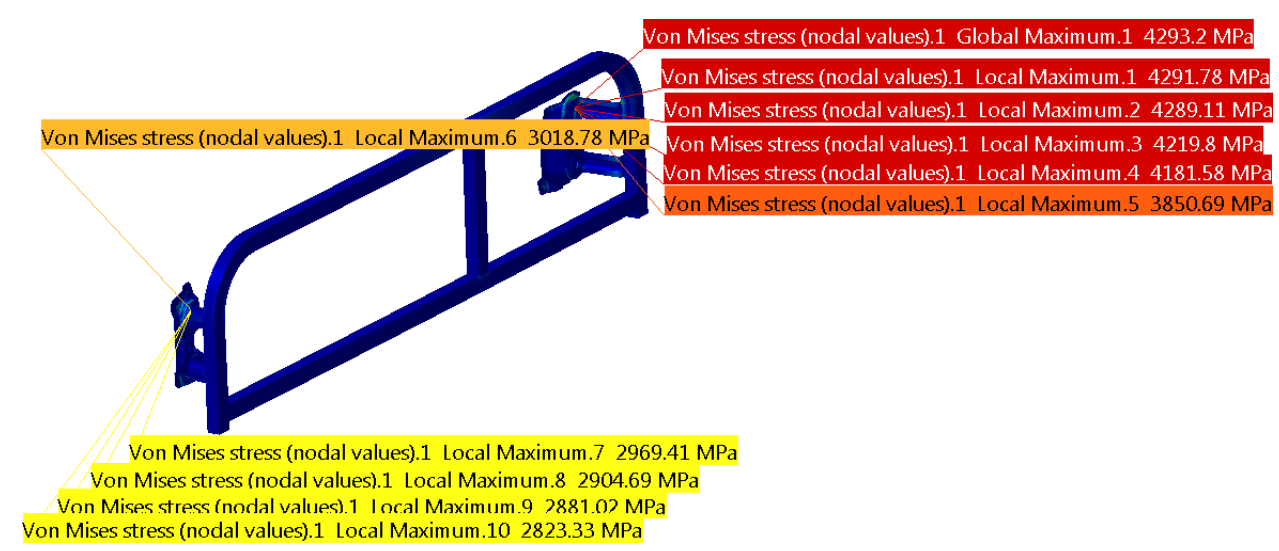

Gambar 8. Tegangan Von Misses yang terjadi pada gaya penarikan $2680 \mathrm{~N}$ arah $\mathrm{x}$.

Pada bagian yang terdeformasi plastis ditandai dengan warna merah pada retainer sisi kanan. Hal ini disebabkan posisi penarikan lebih dekat dengan retainer sisi kanan. Terdapat spot-spot tegangan maksimum yang melebihi kekuatan tarik material hal ini sesuai dengan kondisi aktual pembebanan bahwa terjadi deformasi plastis. Namun tidak ditemukan retakan pada LGF dan distribusi keseluruhan tegangan berada pada daerah aman. 
Gambar 9 menunjukkan perpindahan terbesar terjadi di bagian yang diberikan gaya penarikan sebesar 19,1565 mm.

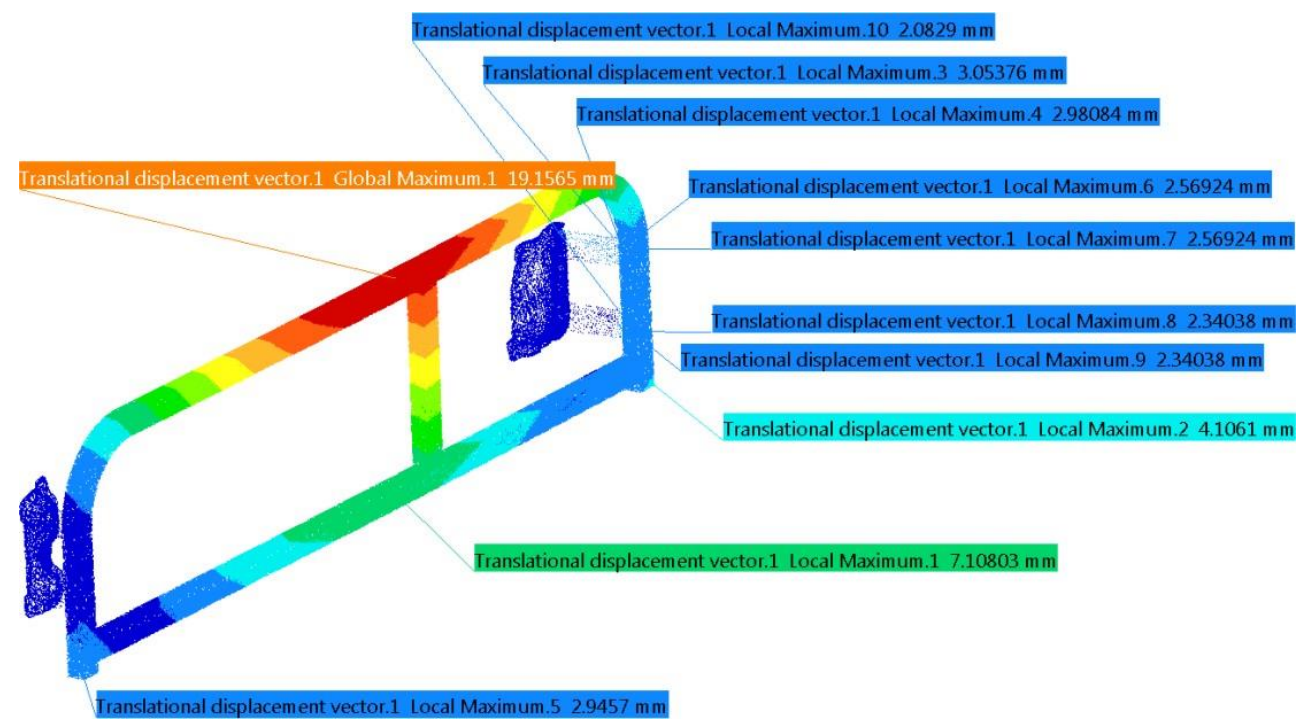

Gambar 9. Perpindahan yang terjadi pada gaya penarikan $2680 \mathrm{~N}$ arah $\mathrm{x}$.

Perpindahan pada pengujian aktual merupakan deformasi total mulai dari panel dinding belakang braket dan LGF pada titik - titik yang ditunjukkan di Gambar 10.

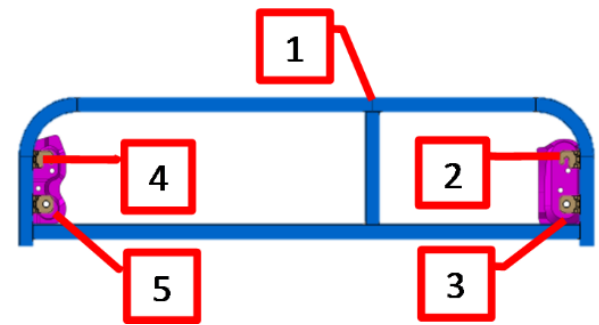

Gambar 10. Posisi pengukuran perpindahan pada pengujian aktual.

Perpindahan yang diperoleh dari analisis Catia pada titik yang sama untuk pengujian aktual ditunjukkan pada Gambar 11.

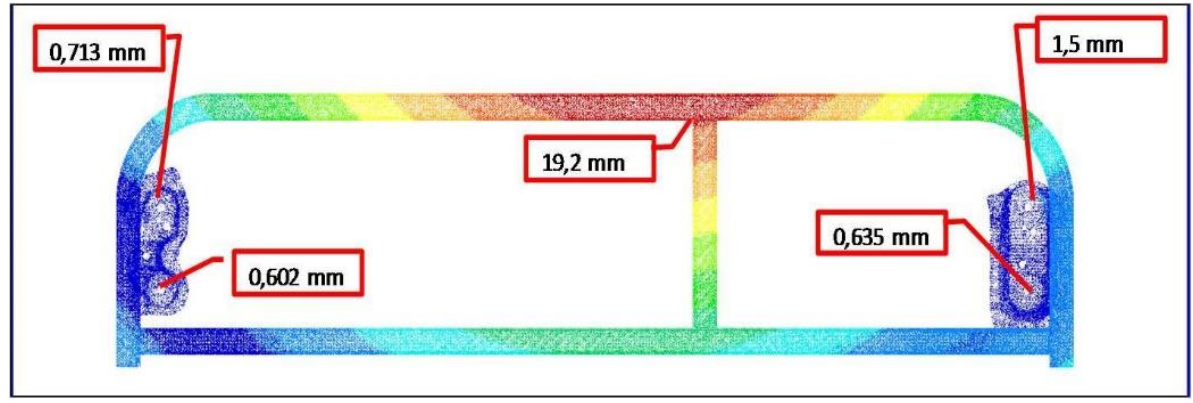

Gambar 11. Hasil Catia untuk perpindahan pada titik-titik yang diukur pada pengujian aktual. 


\section{Analisis pembebanan arah sumbu $\mathbf{Z}$}

Hasil analisis untuk pengujian tekan arah sumbu z ditunjukkan pada Gambar 12 dan Gambar 13. Gambar 12 menunjukkan terjadi tegangan lokal yang melebihi kekuatan material, hal ini sama dengan kondisi penarikan arah $\mathrm{x}$, yaitu LGF mengalami deformasi plastis namun tidak ditemukan retakan.

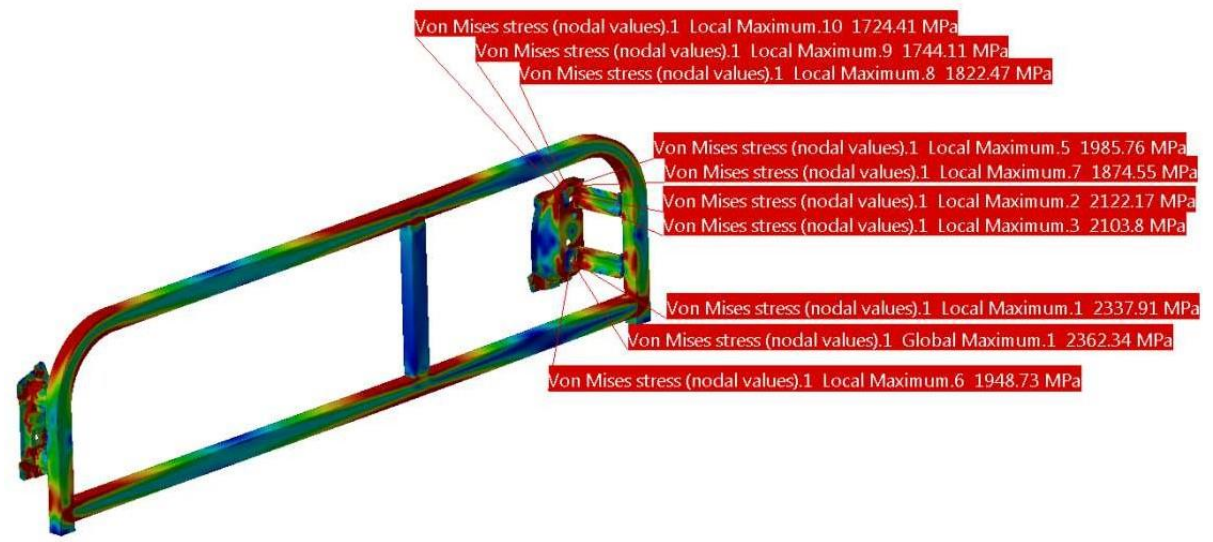

Gambar 12. Tegangan Von Misses pada pembebanan arah z.

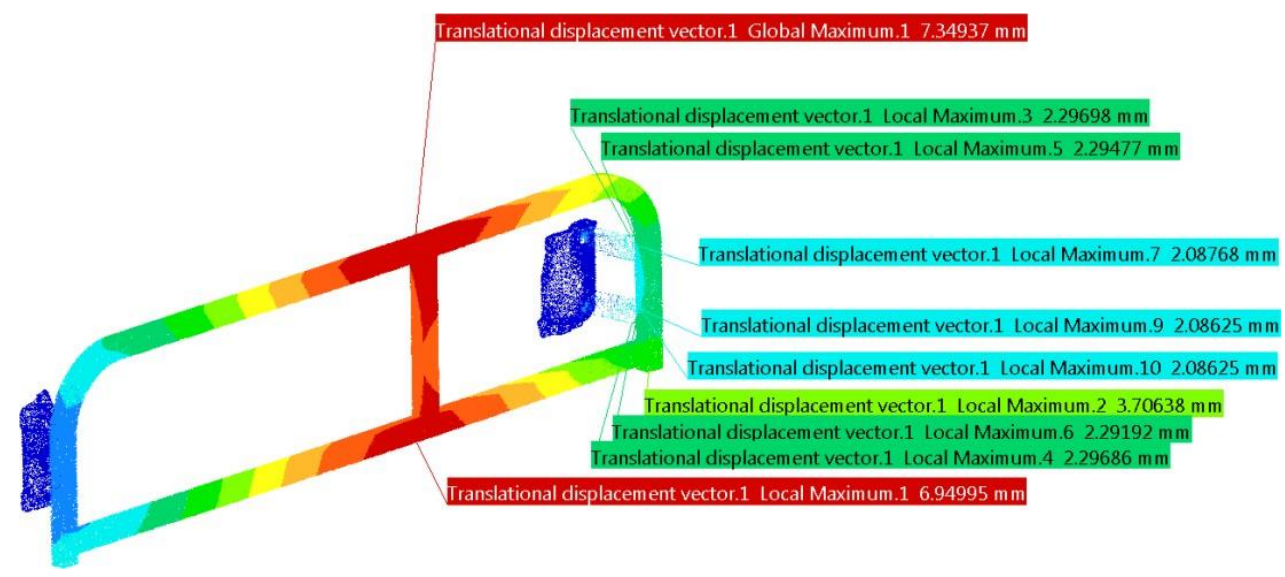

Gambar 13. Perpindahan yang terjadi pada pembebanan arah z.

Perbandingan hasil yang diperoleh dari pengukuran dengan pengujian dan analisis ditunjukkan pada Tabel 3 dan Tabel 4.

Tabel 3. Perbandingan perpindahan pengujian dan Catia untuk penarikan arah $\mathrm{x}$

\begin{tabular}{|c|l|r|r|c|}
\hline No & Komponen & \multicolumn{1}{|c|}{$\begin{array}{c}\text { Actual } \\
\text { Displacement } \\
{[\mathrm{mm}]}\end{array}$} & $\begin{array}{l}\text { Analysis CAE } \\
\text { Displacement } \\
{[\mathrm{mm}]}\end{array}$ & $\%$ \\
\hline 1 & Center Frame & 30,2 & 19,2 & $22,27 \%$ \\
\hline 2 & Bracket RH UPR & & 1,5 & $80,00 \%$ \\
\hline 3 & Bracket RH LWR & 13,5 & & \\
\hline 4 & Bracket LH UPR & & 0,6 & $69,29 \%$ \\
\hline 5 & \multicolumn{1}{|c|}{ Bracket LHLWR } & 3,5 & \multicolumn{3}{|c|}{} \\
\hline
\end{tabular}

Tabel 4. Perbandingan perpindahan pengujian dan Catia untuk penekanan arah y 


\begin{tabular}{|c|l|r|r|c|}
\hline No & \multicolumn{1}{|c|}{ Komponen } & \multicolumn{1}{|c|}{$\begin{array}{c}\text { Actual } \\
\text { Displacement Displala } \\
{[\mathrm{mm}]}\end{array}$} & $\begin{array}{l}\text { Analysis CAE } \\
\text { cement } \\
{[\mathrm{mm}]}\end{array}$ & $\%$ \\
\hline 1 & CenterFrame & 28,3 & 7,4 & $58,77 \%$ \\
\hline 2 & FrameRHUPR & 26,3 & 3,5 & $76,27 \%$ \\
\hline 3 & Bracket RH UPR & & & \\
\hline 4 & FrameLHUPR & 13 & 1,1 & $84,01 \%$ \\
\hline 5 & Bracket LHUPR & & & \\
\hline
\end{tabular}

Dari Tabel 3 dan 4, perpindahan yang terjadi dari seluruh hasil pengukuran lebih besar dari hasil analisis. Beberapa faktor yang menyebabkan perbedaan ini.

Pada saat pembebanan selain LGF, panel kabin dan retainer juga ikut tertarik atau tertekan akibatnya hasil pengukuran LVDT lebih besar dari hasil Catia karena analisis hanya dilakukan pada bagian LGF saja.

Hubungan komponen standar seperti baut dan mur yang dilas dianggap kaku, realitanya terjadi deformasi di bagian ini.

Analisis Catia dilakukan yang dilakukan untuk kondisi elastis memberikan hasil tegangan yang lebih besar karena terjadi perubahan sifat material yang tidak lagi isotrop setelah terdeformasi plastis.

\section{Kesimpulan}

Dari pengujian dan analisis Catia yang sudah dilakukan dapat ditarik kesimpulan:

- Hasil analisis Catia dapat menunjukkan bagian-bagian yang kritis pada LGF sama dengan yang ditunjukkan pada pengujian.

- Analisis Catia tidak mengikutkan panel kabin dan retainer, berbeda dengan kenyataan pada pengujian menyebabkan perbedaan hasil yang signifikan untuk perpindahan.

- Pembebanan yang diberikan menimbulkan deformasi plastis.

\section{Ucapan terima kasih}

Terima kasih kami ucapkan kepada PT ADM tempat dilakukan pengujian dan menyediakan instrumentasi serta benda uji.

\section{Referensi}

[1] PP No 55 tahun 2012. Peraturan Pemerintah Republik Indonesia No 55 tahun 2012 tentang kendaraan. Kendaran. 2012;2:1-92.

[2] Surat Edaran Nomor: SE.2/AJ.307/DRJD/2018. Maret 2018

[3] Daihatsu, A., Model Spesifikasi Himax. Retrieved from Daihatsu Himax, Maret 2018 https://daihatsu.co.id/product/hi-max.

[4] Daihatsu Technical Standard. Galvannealed Steel Sheets and Carbon Steel Tubes for Automobiles. 2018-EN.pdf. 2018:10.

[5] K. I. S. Baidwan , C. R. S. Kumar, Design of Linear Variable Differential Transformer (LVDT) Based Displacement Sensor with Wider Linear Range Characteristics. The International Journal of Technoledge, Vol 3 Issue 4 April (2015) 74-79.

[6] R.G. Budynas, J. K. Nisbeth, Mechanical Engineering, Eighth Edition, United States of America, McGraw-Hill, 2006. 